\title{
Analysis of Methane Concentration Distribution at U-Ventilated Longwall Outlet - Case Study
}

\author{
Adam Niewiadomski, Henryk Badura \\ Silesian University of Technology, Poland \\ Tanyana N. Ivanova \\ Perm National Research Polytechnic Institute, Russia \\ Alexandr Repko, Nikitin R. Yury \\ Kalashnikov Izhevsk State Technical University, Russia
}

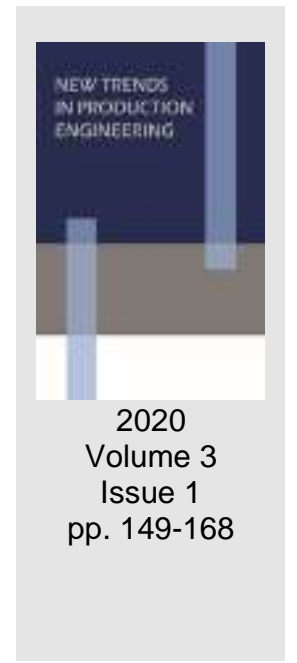

Date of submission to the Editor: 02/2020

Date of acceptance by the Editor: 03/2020

\section{INTRODUCTION}

Longwall exploitation of the seam from parcel boundary towards incline with " $U$ " ventilation system is the most economically justified. The advantage of this solution is the possibility of ventilation drift liquidation, which is usually also the tailgate, along with the longwall progress.

The Regulation of the Minister of Energy on detailed requirements for the operation of underground mining plants (Krause E., Łukowicz K., 2000), currently in force in Poland, introduced additional restrictions for longwall ventilation. One of the most relevant concerns exploitation solution mentioned above and it limits methane bearing capacity in return air content to is $20 \mathrm{~m} / \mathrm{min}$. As the longwall advances, these layers are subject to caving. Such an event is highly unfavorable due to the increase in an endogenous fire threat. It is a result of air migration through the goaf, which oxidizes these fractured coal remains. In order to keep the airflow through the goaf as small as possible, the air volume transported to the longwall area is limited. This action forces the installation of additional methane prevention solutions, such as the air-duct for methaneless or low-methane concentration air transportation to the tailgate and longwall crossing (Fig. 1).

Deformation of the maingate and tailgate also leads to the methane safety conditions deterioration (Krause E., Wierzbiński K, 2009).

Methane drainage has a meaningful role in maintaining safe working conditions due to methane hazard. In Poland, there is extensive experience in the application of the longwalls methane drainage during the exploitation (with boreholes and corridor headings located above the exploited seam), as well as the post-exploitation goafs drainage (Berger J. et al., 2011, Jakubów A., 2014, Szlązak N., et al., 2014). In line with the global approach, the captured methane is treated as fuel (Karacan C.Ö., et al., 2011, Uszko M., et al., 2014) used for heat and electricity production. 
During the project stage of longwall, if methane hazard is identified, it is essential to plan appropriate methane prevention solutions. Planning and selection of these measures could be prepared based on the absolute methane prediction model (Krause E., Łukowicz K., 2015, Lunarzewski L. W., 1998).

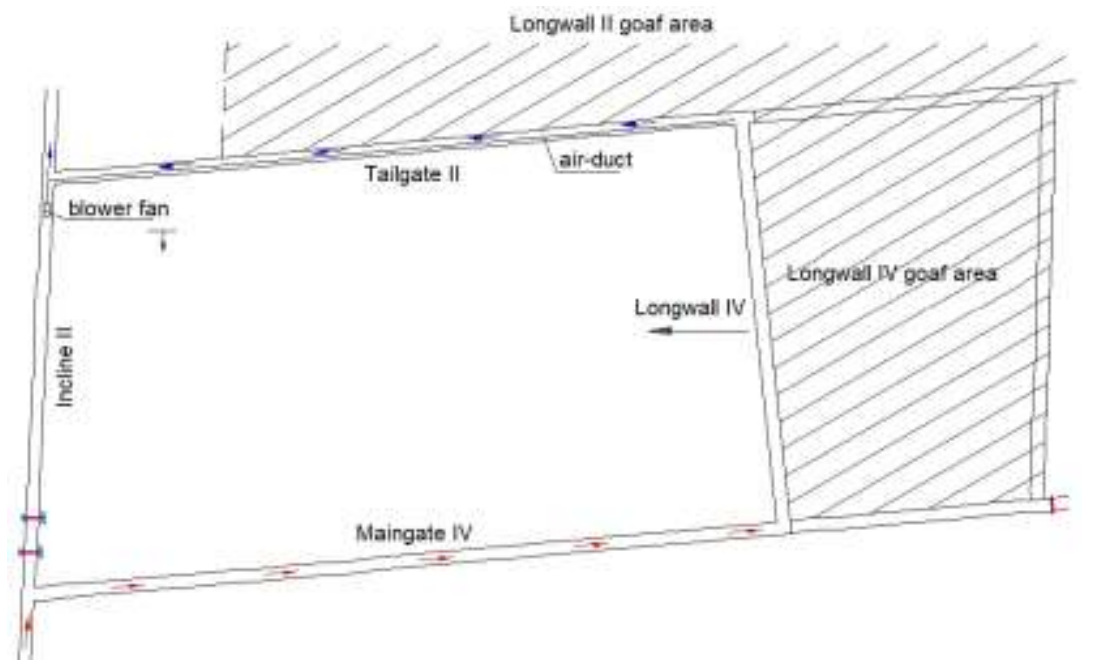

Fig. 1 Longwall IV in seam 501/1 area

This model utilizes determined methane distribution in longwall parcel (Zawadzki J., at al.). However, more accurate identification of the methane hazard level is possible only after the exploitation launch. This issue is the subject of numerous research publications (Badura H., 2007a, Badura H., 2007b, Badura H., 2009, Badura H., 2013, Karacan C.Ö., Diamond W.P., 2006, Karacan C.Ö., 2008, Karacan C.Ö., 2009, Krause E., 2015, Noack K., 1998). In recent years, computational fluid dynamics (CFD) models have been also widely used to learn the distribution of methane concentration in return air and longwall goafs (Lolon et al. 2017, Wierzbiński 2016, Zongyi et al. 2015). This method was utilized (Branny M. 2006), among others, for research on the influence of auxiliary fans installed at longwall outlet on the methane-air mixture dilution.

The paper (Dittman P., 2000) concludes the research and CFD simulations results of the methane layer dispersion in the $U$-ventilated longwall tailgate. The calculations covered the air velocity variable in the range from $0.5 \mathrm{~m} / \mathrm{s}$ to $5 \mathrm{~m} / \mathrm{s}$. It was found that only a speed above $3 \mathrm{~m} / \mathrm{s}$ ensures an acceptable safety level. Moreover, in the publication (Wierzbiński 2016), author also using CFD, considered the influence on methane hazard of the auxiliary ventilation measures application at the longwall - tailgate crossing. Presented results indicate that the auxiliary ventilation measures utilization leads to a significant reduction in the risk of dangerous methane concentrations occurrence. Solutions involving the use of a ventilation brattice in a tailgate are often practising in longwall mining (Uszko M., et al.2014).

Regulations in Poland indicate that if the predicted methane bearing capacity exceeds $10 \mathrm{~m}^{3} / \mathrm{min}$, the required minimum cross-sectional area of tailgate between the ventilation brattice and the opposite heading wall should be at least 
$6 \mathrm{~m}^{2}$ (Regulation, 2017). This requirement is difficult to meet when the exploited longwall field is located in the direct vicinity of previous longwall goafs and could force temporary disassembly of brattice.

This article presents a comparative analysis of methane concentrations registered by the sensors located at the crossing of the longwall IV in seam $505 / 1$ and tailgate II and an additional sensor located at tailgate II outlet 10-15 $\mathrm{m}$ from the incline II.

\section{Geological and mining parameters of the longwall iv in seam 505/1}

The thickness of 505/1 seam in the longwall IV parcel varied from $2.6 \mathrm{~m}$ to $4.15 \mathrm{~m}$. The ceiling (up to $60 \mathrm{~m}$ ) was mainly formed of sandstones (about $90 \%$ ) with thin layers of clay, shale and coal. In the direct seam floor, there were layers of clay, shale and seam 505/2 characterized by high thickness changeability. Beneath this set of layers were sandstone.

Longwall IV length varied from 212 to $217 \mathrm{~m}$, and panel length was ca. $425 \mathrm{~m}$. Face height varied in the $2,9 \mathrm{~m}$ to $3,7 \mathrm{~m}$ range. The longitudinal slope of the longwall ranged from $16^{\circ}$ to $19^{\circ}$, and the transverse slope from $-5^{\circ}$ to $3^{\circ}$.

The closest already exploited seams were located in the vertical distance of $90 \mathrm{~m} \mathrm{(502/1} \mathrm{seam)} \mathrm{and} 160 \mathrm{~m}(418 / 1-2$ seam). The thicknesses of these seams ranged from $2,5 \mathrm{~m}$ to $2,7 \mathrm{~m}$.

The diagram of the longwall area is shown in Figure 1. The maingate and tailgate were made of an incline II. The longwall operation was started from the raise IVa and led from north to south, towards incline II.

The following hazard categories, according to Polish law regulations, occurred in the area of longwall IV:

1. methane hazard category IV,

2. coal dust explosion hazard class B,

3. coal self-combustion hazard group II,

4. excavation flooding hazard I,

5. rockburst hazard I,

6. gas and rock outburst hazard not threatened.

The absolute methane bearing capacity forecast for daily exploitation volume of $4000 \mathrm{t} /$ day was $13 \mathrm{~m}^{3} \mathrm{CH}_{4} / \mathrm{min}$.

Moreover, from day 124 of exploitation until its end, methane drainage was applied.

The location of the methane sensors in the tailgate II and at the longwall IV outlet is shown in Figure 2. The fresh air to the longwall, in the amount of $1300 \mathrm{~m} / \mathrm{min}$, was supplied from excavations at the $900 \mathrm{~m}$ level, by incline II and then by maingate IV.

In order to mitigate the methane hazard level, additional air in the amount of 500 $\mathrm{m} 3 / \mathrm{min}$ was supplied by the air-duct to the longwall outlet. Connected to the air-duct blower fan was located in inline II in fresh air (Fig. 1).

The return air was transported from the longwall IV by tailgate II to incline II, and then to the excavations at the $705 \mathrm{~m}$ level. 


\section{Ventilation parameters and methane sensors at the longwall iv and tailgate ii crossing}

The positioning of methanometric sensors in the longwall II outlet area and the vicinity of tailgate II and inline II crossing is shown in Figure 2. The location of these sensors was in accordance with the mining regulations currently in force in Poland.

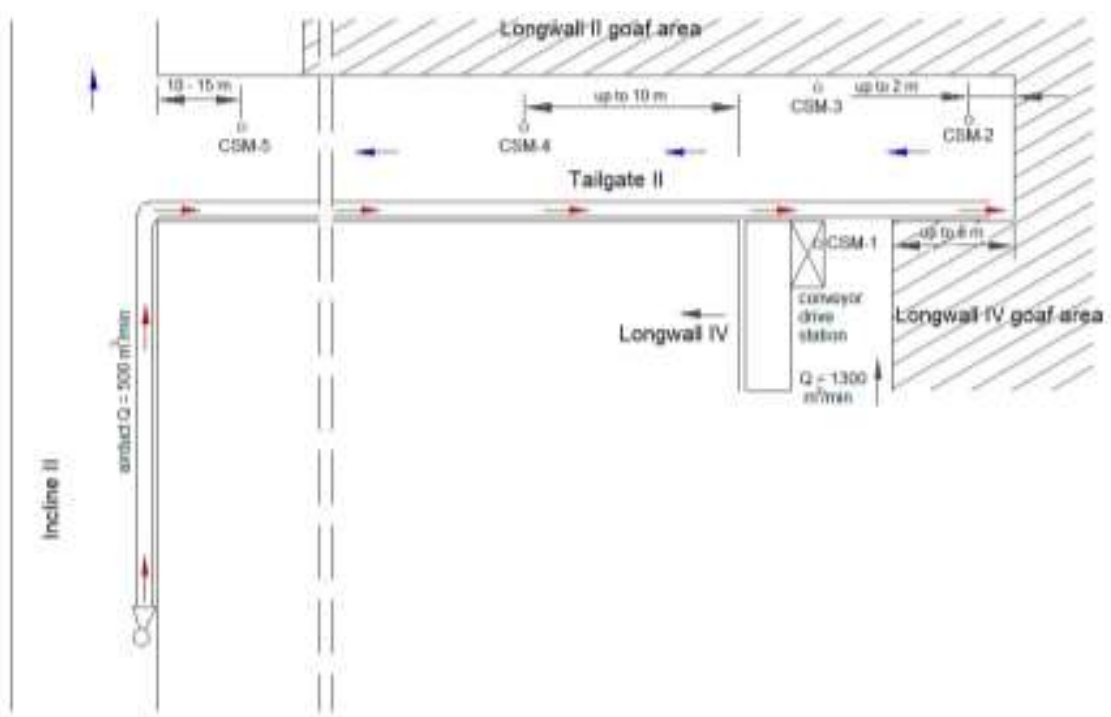

Fig. 2 Diagram of longwall IV and tailgate II crossing

The CSM-1 sensor was located in the longwall, in direct vicinity to conveyor drive station. The sensor was placed not lower than $10 \mathrm{~cm}$ under the ceiling of the powered roof support. The CSM-2 sensor was located up to $2 \mathrm{~m}$ from the tailgate caving line in the methane-air mixing zone. The distance from the tailgate to the longwall caving line was variable but did not exceed $6 \mathrm{~m}$. The CSM-3 sensor was located at the tailgate wall in opposite to the longwall outlet. The CSM-4 sensor was in the tailgate, up to $10 \mathrm{~m}$ from the longwall outlet. The CSM-5 sensor was located at the tailgate at a distance of 10-15 $\mathrm{m}$ from the incline II. The CSM-2, CSM-4, CSM-5 sensors were placed not lower than $10 \mathrm{~cm}$ under the ceiling support at its highest.

The threshold methane concentration at the sensors was set as $2 \% \mathrm{CH}_{4}$. All sensors had a function to switch off electricity in the tailgate, longwall and maingate up to $10 \mathrm{~m}$ from the longwall inlet.

\section{METHODS OF RESEARCH}

The whole observation data set covered 249 days of methane concentration constant measurement. It was assumed, according to the work shift routine in the mine, that the measurement day began at 6:00:00 $\mathrm{AM}$ and ended at 5:59:59 AM on the following day.

The methane measurement system archives the registered data in the form of records set as shown in Table 1. The first column contains a series of dates and starts times of each methane concentration measurement. In the second 
column, the measurement value of methane concentration is registered with an accuracy of $0.1 \%$.

Table 1 Sample set of methane measurements

\begin{tabular}{|c|c|c|c|}
\hline 0.09 .2018 & $8: 46: 35$ & $0.3 \% \mathrm{CH}_{4}$ & 0:00:48| \\
\hline 26.0 & $8: 46: c$ & $0.4 \% \mathrm{CH}_{4}$ & 0:00:10| \\
\hline 26 & $8: 46: 0$ & $0.5 \% \mathrm{CH}_{4}$ & $0: 00: 16 \mid$ \\
\hline & & $0.4 \% \mathrm{CH}_{4}$ & 0:00:22| \\
\hline & & $0.3 \% \mathrm{CH}_{4}$ & 14 \\
\hline 01 & & $0.2 \% \mathrm{CH}_{4}$ & 05:02| \\
\hline 018 & & & \\
\hline
\end{tabular}

The third column records the methane concentration duration of the value given in the second column. The fourth column contains additional information and comments (e.g., scaling of the sensor or exceeding set concentration threshold). Column 4 in the presented sample is empty, which means there were no significant events due to the methane hazard at the location of this sensor. The developed at the Silesian University of Technology PROGMET application allowed the transformation of the measurement data set into usable for further analysis variables. The sample extract from a CSV database is shown in Table 2.

Table 2 Sample extract from PROGMET database

\begin{tabular}{|c|c|c|c|c|c|c|c|c|c|c|c|c|c|c|}
\hline Day & Av & Min & Max & $\mathbf{0 . 1}$ & $\mathbf{0 . 2}$ & $\mathbf{0 . 3}$ & $\mathbf{0 . 4}$ & $\mathbf{0 . 5}$ & $\mathbf{0 . 6}$ & $\mathbf{. . . .}$ & $\mathbf{1 . 9}$ & $\mathbf{2 . 0}$ & $\begin{array}{c}\text { Total } \\
\text { time }\end{array}$ & Sampler \\
\hline 1 & 0.41 & 0.3 & 0.5 & 0 & 0 & 9025 & 63185 & 14190 & 0 & $\ldots .$. & 0 & 0 & 86400 & 134 \\
\hline 2 & 0.46 & 0.4 & 0.6 & 0 & 0 & 0 & 39398 & 41668 & 5334 & $\ldots .$. & 0 & 0 & 86400 & 99 \\
\hline
\end{tabular}

The first column acts as a counter and contains the number of the measurement day from the beginning of the set. The 'Av' column shows the values of the average methane concentrations, calculated as a weighted average based on the specific methane concentrations value and their duration time on the day under consideration. In the columns 'Min' and 'Max', there are respectively a minimum and a maximum recorded methane concentration values on a given day. Columns marked '0.1' to '2.0' contain the total time (in seconds) of specified in header methane concentration occurrence. For example, on day 1, the time of occurrence of $0.3 \% \mathrm{CH}_{4}$ concentration was 9025 seconds and on day 2 , the total time of occurrence of $0.6 \% \mathrm{CH}_{4}$ concentration was 5334 seconds. "Sum of time" is the control column and contains the sum of the times that individual methane concentrations occur on a given measurement day. Its value should be 86400 (number of seconds in a day). The "Sampler" column informs about the number of records in a given day, i.e. number of changes in registered methane concentration by $0.1 \%$ or more. The number of rows of the database corresponds to the number of complete measurement days. In this case it is 249. The longwall IV database, prepared according to the presented procedure, was the basis for further analyses. 


\section{RESULTS AND DISCUSSIONS}

Based on the obtained data, average values and maximum methane concentration on selected days of observation were determined. The presented data include measurement from CSM-1 to CSM-5 sensors (Fig. 3-7).

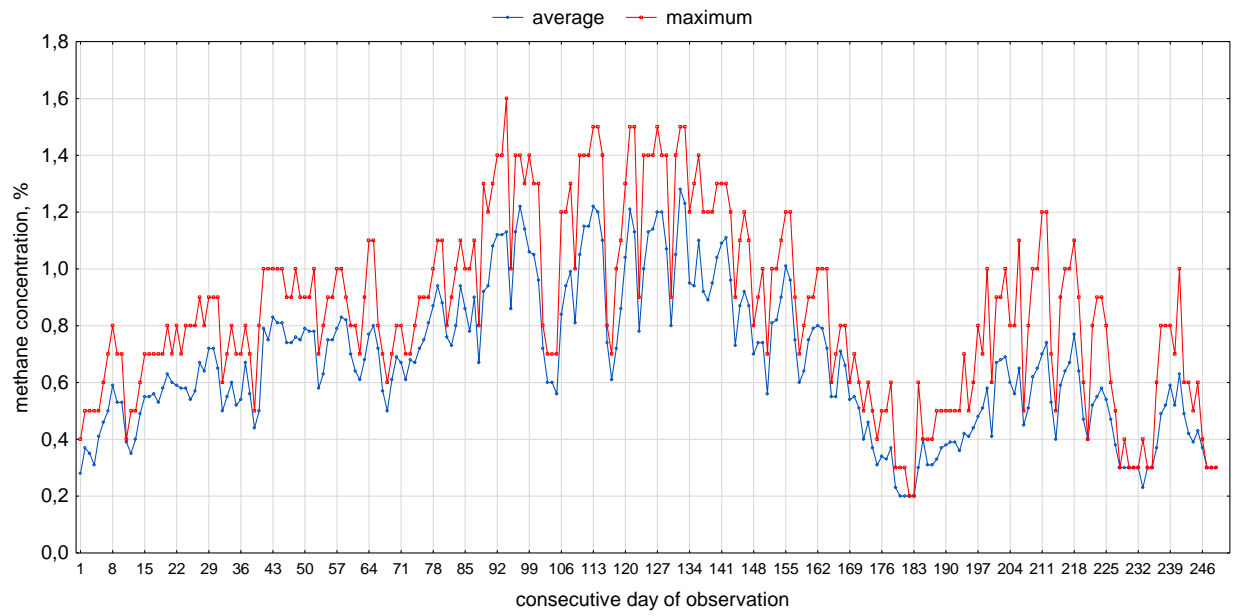

Fig. 3 Average and maximum methane concentration in the tailgate, 10-15 m from inline II crossing (CSM-5)

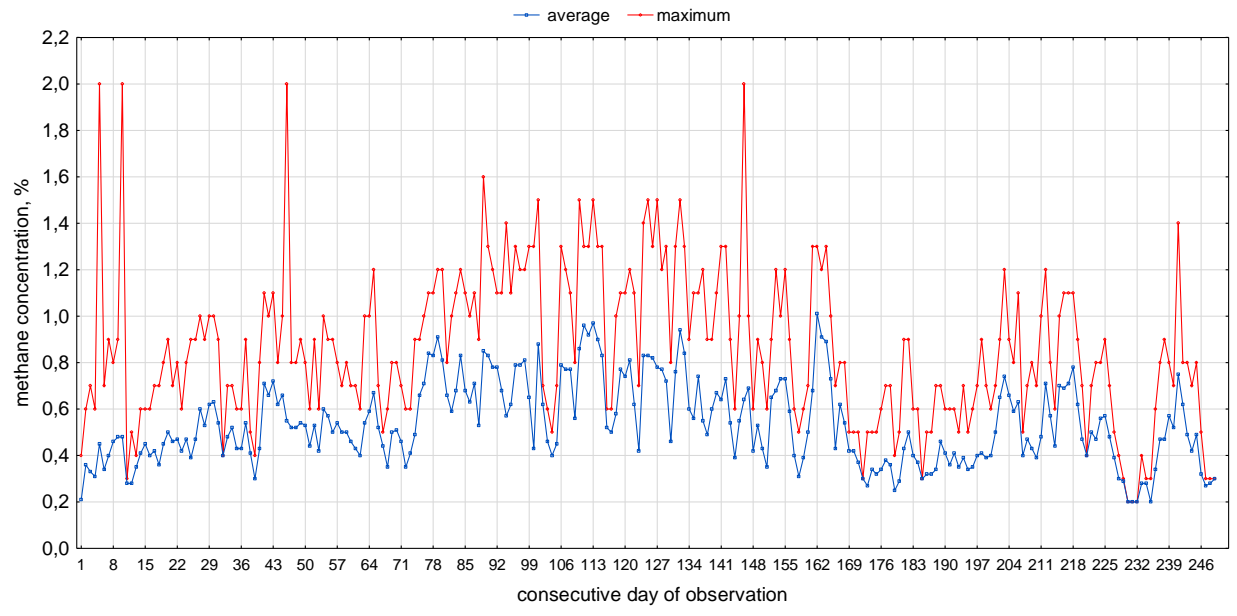

Fig. 4 Average and maximum methane concentration in the tailgate, $10 \mathrm{~m}$ from longwall crossing (CSM-4)

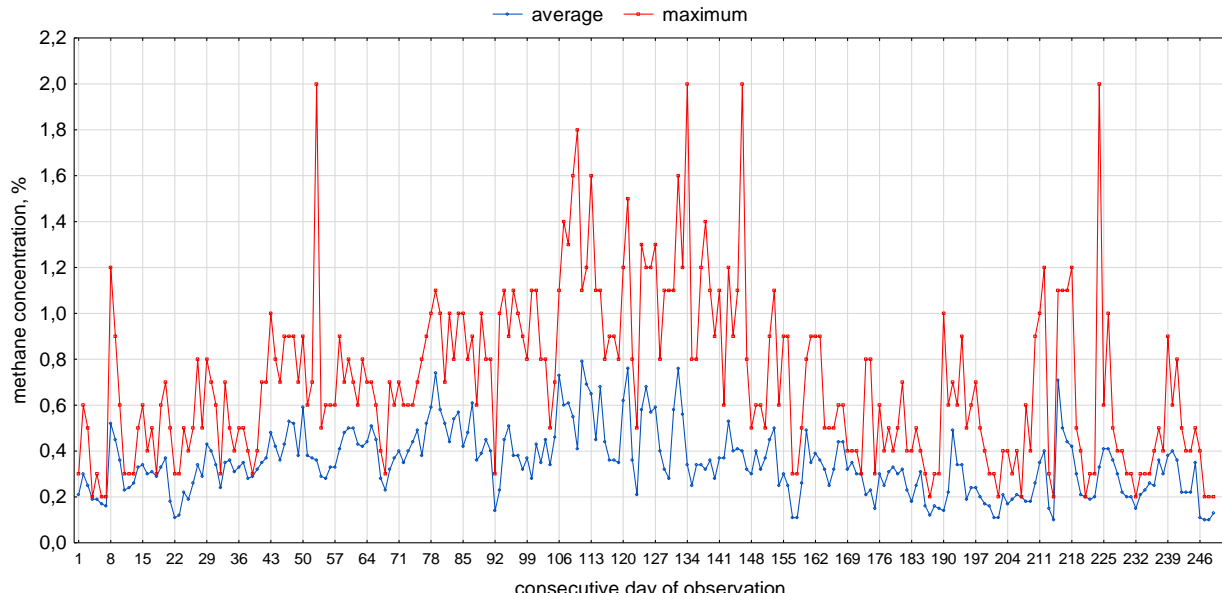

Fig. 5 Average and maximum methane concentration at the tailgate wall in opposite to the longwall outlet (CSM-3) 


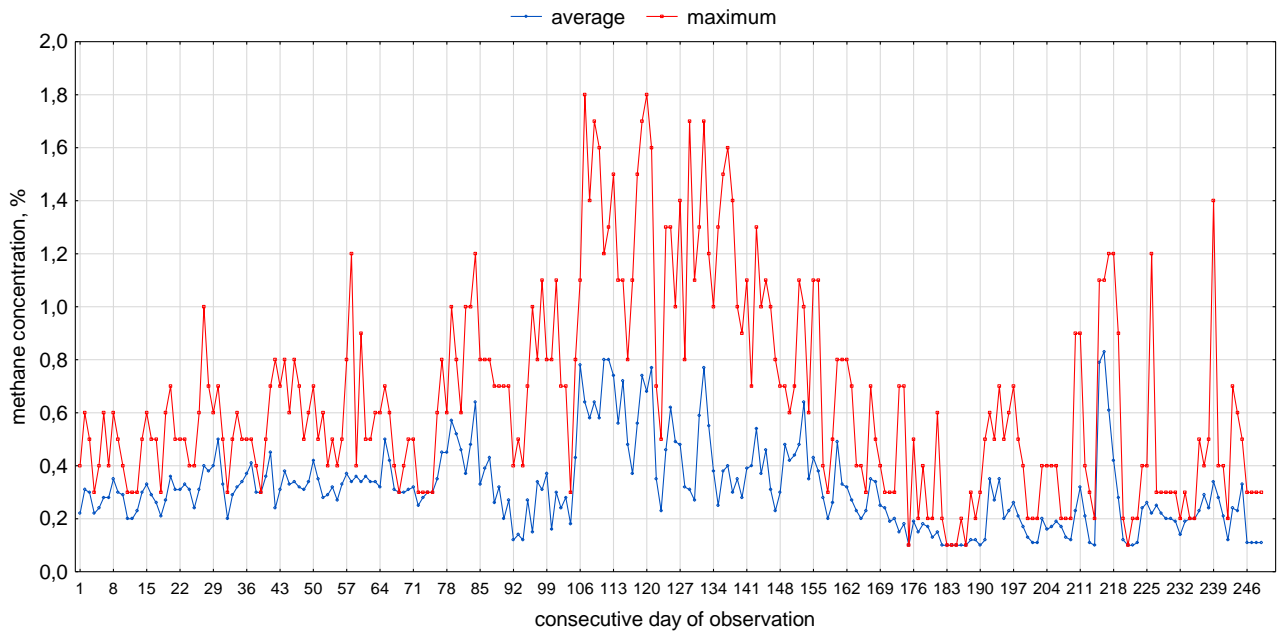

Fig. 6Average and maximum methane concentration at the tailgate, $2 \mathrm{~m}$ from the tailgate caving line (CSM-2)

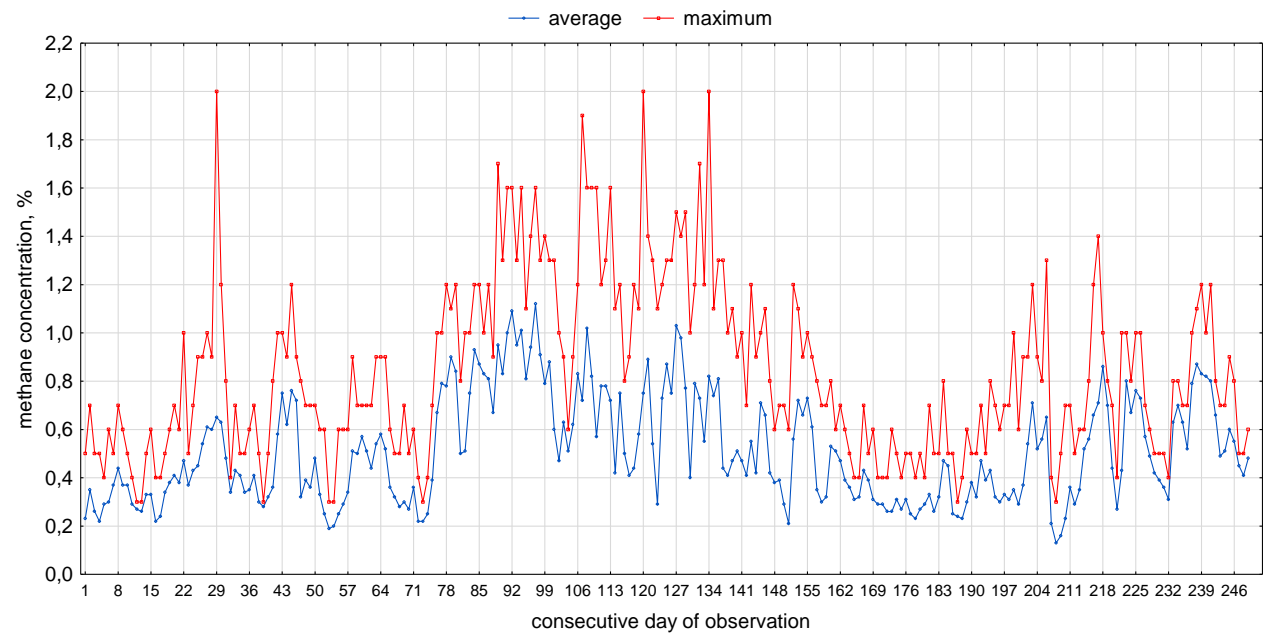

Fig. 7 Average and maximum methane concentration at the tailgate, in direct vicinity to conveyor drive station (CSM-1)

A comparison of the methane concentration graphs (Fig. 3-7) shows apparent differences between registered values. Three of the sensors, CSM-2, CSM-3 and CSM-4, are located in the tailgate at direct vicinity from each other. Table 3 summarizes the statistical parameters characterizing the variability of mean and maximum registered methane concentration at these sensors.

Table 3 Statistical parameters of methane concentrations registered at CSM-2, CSM-3 and CSM-4 sensors

\begin{tabular}{|l|c|c|c|c|c|c|}
\hline \multicolumn{1}{|c|}{ Sensor } & \multicolumn{2}{c|}{ CSM-2 } & \multicolumn{2}{c|}{ CSM-3 } & \multicolumn{2}{c|}{ CSM-4 } \\
\hline $\mathrm{CH}_{4}$ concentration & Average & Maximum & Average & Maximum & Average & Maximum \\
\hline mean, \% $\mathrm{CH}_{4}$ & 0.32 & 0.66 & 0.35 & 0.70 & 0.53 & 0.86 \\
\hline median, \% $\mathrm{CH}_{4}$ & 0.30 & 0.6 & 0.34 & 0.6 & 0.50 & 0.8 \\
\hline 90 $0^{\text {th }}$ percentile, \% $\mathrm{CH}_{4}$ & 0.52 & 1.2 & 0.53 & 1.1 & 0.79 & 1.3 \\
\hline minimum, \% $\mathrm{CH}_{4}$ & 0.10 & 0.1 & 0.10 & 0.2 & 0.20 & 0.2 \\
\hline maximum, \% $\mathrm{CH}_{4}$ & 0.83 & 1.8 & 0.79 & 2.0 & 1.01 & 2.0 \\
\hline range, \% $\mathrm{CH}_{4}$ & 0.73 & 1.7 & 0.69 & 1.8 & 0.81 & 1.8 \\
\hline $\begin{array}{l}\text { standard deviation, } \\
\text { \% } \mathrm{CH}_{4}\end{array}$ & 0.16 & 0.40 & 0.14 & 0.36 & 0.18 & 0.33 \\
\hline coefficient of variation, \% & 49.7 & 58.3 & 41.2 & 55.6 & 33.2 & 38.8 \\
\hline summ, \% $\mathrm{CH}_{4}$ & 78.69 & 163.2 & 86.46 & 175.7 & 133.39 & 214.3 \\
\hline
\end{tabular}


The CSM-2 sensor registers air-methane mixture, which migrates from the goaf and the liquidated part of the tailgate, directly from the longwall and the air supplied by the air-duct.

The CSM-3 sensor, located opposite the longwall outlet, measured the concentration of methane in the air flowing from the tailgate liquidation zone and the longwall.

The CSM-4 sensor registered the airflow, which is a sum of the longwall flow, the goaf and supplied by the air-duct.

The data presented in Table 2 show that the average methane concentration increased with the direction of airflow. From $0.32 \% \mathrm{CH}_{4}$ at $2 \mathrm{~m}$ from tailgate caving zone (sensor CSM-2) to $0.53 \% \mathrm{CH}_{4}$ at $10 \mathrm{~m}$ from longwall outlet (sensor CSM-4).

It should be noted that at least half of the observation days, the average methane concentration recorded by the CSM-2 did not exceed $0.30 \% \mathrm{CH}_{4}$, by the CSM$3-0.34 \% \mathrm{CH}_{4}$, and by the CSM- $4-0.50 \% \mathrm{CH}_{4}$.

The 90th percentile value also raises according to airflow direction from the CSM-2 to CSM-4. It means that in $10 \%$ of the days of observation, the average methane concentration took values in the range from the value equal to the $90^{\text {th }}$ percentile to the maximum value. For CSM-2 sensor this range is defined by the limits $(0.52 \%, 0.83 \%)$, for CSM-3 sensor $-(0.59 \%, 0.79 \%)$, and for CSM-4 sensor - $(0.79 \%, 1.01 \%)$.

The standard deviation can be utilized as a measure of the absolute values variation in sets of average methane concentrations.

The highest standard deviation $\left(0.18 \% \mathrm{CH}_{4}\right)$ assumes set of average methane concentration values recorded by the CSM- 4 sensor, a slightly lower value of this parameter $\left(0.16 \% \mathrm{CH}_{4}\right)$ has a set of average methane concentration near the tailgate caving zone (CSM-2), and the lowest $\left(0.14 \% \mathrm{CH}_{4}\right) \mathrm{CSM}-3$ dataset (CSM-3).

The variability of methane concentration could also be characterized by the coefficient of variation, which is the quotient of standard deviation by a set of the methane concentrations average value in percentage (i.e. it is a relative measure of variability). Based on this coefficient it can be stated that the highest relative variability characterizes the average methane concentration set registered near the tailgate caving zone (coefficient of variation equal to $49.7 \%$ ), then at the location of the CSM-3 sensor (coefficient of variation equal to $41.2 \%$ ) and the lowest at the location of the CSM-4 sensor (coefficient of variation equal to $33.2 \%$ ).

Conducted tests proved that analyzed methane concentration sets have nonnormal distribution. Therefore it is assumed that distribution is undetermined. According to Chebyshev's inequality, in such a case, the range: (mean value $\pm 2^{*}$ standard deviation) should include at least $75 \%$ of the registered average values (Dittmann P, 2000). In the analyzed dataset, not less than $75 \%$ of the average values are in the following ranges:

- CSM-2 sensor - $(0.10 \%, 0.64 \%)$,

- CSM-3 sensor - $(0.10 \%, 0.63 \%)$, 
- CSM-4 sensor - $(0.20 \%, 0.89 \%)$.

The lower limit of the compartment is determined by the minimum value of the average methane concentration at the sensor location.

Average methane concentration parameters (except for the coefficient of variation) indicate that the highest variability of the average methane concentration occurred at the location of the CSM-4 sensor.

The maximum values of methane concentration registered by CSM-2, CSM-3 and CSM-4 sensors were also part of the analysis. The mean of maximum methane concentrations at a distance of up to $2 \mathrm{~m}$ from tailgate caving zone (CSM-2) is $0.66 \% \mathrm{CH}_{4}$, opposite the longwall outlet $0.70 \% \mathrm{CH}_{4}(\mathrm{CSM}-3)$, and $10 \mathrm{~m}$ from longwall outlet (CSM-4) $0.86 \% \mathrm{CH}_{4}$, i.e. the mean value of maximum concentration increases with the distance from the gallery caving line. The median of maximum methane concentrations at the location of CSM-2 and CSM-3 is $0.6 \% \mathrm{CH}_{4}$, while at the location of CSM- $4-0,8 \% \mathrm{CH}_{4}$. The values of the maximum concentration $90^{\text {th }}$ percentile are $1.2 \% \mathrm{CH}_{4}, 1.1 \% \mathrm{CH}_{4}$ and $1.3 \%$ $\mathrm{CH}_{4}$ for CSM-2, CSM-3 and CSM-4, respectively. As previously, the values increase according to the direction of airflow.

The highest value of the maximum methane concentration registered by the CSM-2 sensor was $1.8 \% \mathrm{CH}_{4}$. The other sensors registered maximum values of $2.0 \% \mathrm{CH}_{4}$. At the CSM-3 sensor concentration of $2.0 \% \mathrm{CH}_{4}$ occurred four times: in 53, 134, 146 and 224 days of observation set. The CSM-4 sensor recorded $2.0 \% \mathrm{CH}_{4}$ in 5, 10, 46 and 146 days of observation. Therefore, only on day 146 the $2.0 \% \mathrm{CH}_{4}$ was observed at both sensors simultaneously.

The standard deviation of the maximum methane concentration is $0.40 \% \mathrm{CH}_{4}$ at the CSM-2, $0.36 \% \mathrm{CH}_{4}$ at the CSM-3 and $0.33 \% \mathrm{CH}_{4}$ at CSM-4 sensor. The decreasing values of standard deviation as the distance from the tailgate caving line increases allow the assumption that air-methane mixture homogeneity raises. The coefficient of variation also has a downward trend from the caving line towards the tailgate outlet. It means that relative fluctuations of maximum methane concentration decrease, although the average values increase with the direction of airflow.

The obtained values of standard deviations and coefficients of variation of maximum methane concentrations are higher than those of the average methane concentration, which is understandable because of the higher randomness of registered maximum concentrations resulting from shorter occurrence times. Average methane concentrations were calculated based on thousands of measurements.

The parameters concluded in Table 3 show that no less than $75 \%$ of the maximum methane concentration values are in the ranges:

- at CSM-2 sensor - $(0.1 \%, 1.3 \%)$,

- at CSM-3 sensor - $(0.2 \%, 1.4 \%)$,

- at CSM-4 sensor - $(0.2 \%, 1.5 \%)$.

Table 4 summarizes statistical parameters of measured methane concentration in the longwall, near its outlet (CSM-1), in the tailgate up to $10 \mathrm{~m}$ before the 
longwall/tailgate crossing (CSM-4) and in the tailgate outlet, 10-15 m before the crossing with incline II (CSM-5).

Table 4 Statistical parameters of methane concentrations registered at CSM-1, CSM-4 and CSM-5 sensors

\begin{tabular}{|l|c|c|c|c|c|c|}
\hline \multicolumn{1}{|c|}{ Sensor } & \multicolumn{2}{c|}{ CSM-1 } & \multicolumn{2}{c|}{ CSM-4 } & \multicolumn{2}{c|}{ CSM-5 } \\
\hline $\mathrm{CH}_{4}$ concentration & Average & Maximum & Average & Maximum & Average & Maximum \\
\hline mean, \% $\mathrm{CH}_{4}$ & 0.51 & 0.84 & 0.53 & 0.86 & 0.67 & 0.86 \\
\hline median, \% CH 4 & 0.45 & 0.8 & 0.50 & 0.8 & 0.65 & 0.8 \\
\hline $90^{\text {th }}$ percentile, \% $\mathrm{CH}_{4}$ & 0.82 & 1.3 & 0.79 & 1.3 & 1.05 & 1.3 \\
\hline minimum, \% $\mathrm{CH}_{4}$ & 0.10 & 0.3 & 0.20 & 0.2 & 0.20 & 0.2 \\
\hline maximum, \% $\mathrm{CH}_{4}$ & 1.12 & 2.0 & 1.01 & 2.0 & 1.28 & 1.6 \\
\hline range, \% $\mathrm{CH}_{4}$ & 0.99 & 1.7 & 0.81 & 1.8 & 1.08 & 1.4 \\
\hline $\begin{array}{l}\text { standard deviation, } \\
\% \mathrm{CH}_{4}\end{array}$ & 0.22 & 0.36 & 0.18 & 0.33 & 0.25 & 0.32 \\
\hline coefficient of variation, \% & 43.05 & 43.09 & 33.20 & 38.8 & 37.87 & 36.95 \\
\hline summ, \% $\mathrm{CH}_{4}$ & 126.38 & 209.2 & 133.39 & 214.3 & 166.77 & 213.0 \\
\hline
\end{tabular}

The CSM-1 sensor registers methane concentration in the air stream transported through the longwall, while the CSM-4 and CSM-5 sensors measure methane concentration in the return air. The mean value of methane concentration in the longwall outlet is $0.51 \% \mathrm{CH}_{4}$ (CSM-1), $10 \mathrm{~m}$ from its outlet, in tailgate $-0.53 \% \mathrm{CH}_{4},(\mathrm{CSM}-4)$, and the tailgate outlet $-0.67 \% \mathrm{CH}_{4}(\mathrm{CSM}-5)$. It confirms the trend noted earlier that the average concentration of methane increases with the direction of airflow. It may be caused by the inflow of methane to the ventilation sidewalk from the goaf and by the emission from the coal longwall IV unexploited parcel part. The median value of the average methane concentration distribution is similar. For CSM-1 sensor it is $0.45 \% \mathrm{CH}_{4}$, for CSM-4 sensor $-0.50 \% \mathrm{CH}_{4}$ and for $\mathrm{CSM}-1$ sensor $-0.65 \% \mathrm{CH}_{4}$.

Taking into consideration the maximum values and 90th percentiles of average methane concentration, it should be noted that for $10 \%$ of the observation days the registered average concentration was in the range $\left(0.82 \% \mathrm{CH}_{4}, 1.12 \% \mathrm{CH}_{4}\right)$ at the CSM-1, $\left(0.79 \% \mathrm{CH}_{4}, 1.01 \% \mathrm{CH}_{4}\right)$ at the CSM-4 and in the range $(1.05 \%$ $\left.\mathrm{CH}_{4}, 1.28 \% \mathrm{CH}_{4}\right)$ at the CSM-5 sensor. The value range is respectively $0.30 \%$ $\mathrm{CH}_{4}, 0.22 \% \mathrm{CH}_{4}$, and $0.23 \% \mathrm{CH}_{4}$. The highest fluctuation range of registered concentrations in the $10 \%$ of the upper range of population was therefore recorded for the CSM-1 sensor, located in the longwall near its outlet, above conveyor drive station. The range of whole set of average methane concentration is $0.99 \% \mathrm{CH}_{4}$ for CSM-1, $0.81 \% \mathrm{CH}_{4}$ for CSM-4 and $1.08 \% \mathrm{CH}_{4}$ for CSM-5.

The statistical parametrs (Table 4 ) show that no less than $75 \%$ of the average values of the methane concentration are within the ranges:

- at the location of CSM-1 sensor - $(0.10 \%, 0.95 \%)$,

- at the location of CSM-4 sensor - $(0.20 \%, 0.89 \%)$,

- at the location of CSM-5 sensor - $(0.20 \%, 1.17 \%)$.

The lower limits of the ranges result from minimum values of average methane concentrations. The highest range of values reaches data obtained from the outlet from the longwall area. 
The maximum methane concentration at the CSM-1 sensor location had a mean value of $0.84 \% \mathrm{CH}_{4}$ and for CSM- 4 and CSM- 5 sensors are $0.86 \% \mathrm{CH}_{4}$. Medians of maximal methane concentrations are equal for the analyzed measurements with the CSM-1, CSM- 4 and CSM- 5 sensors $-0,8 \% \mathrm{CH}_{4}$. Also, $90^{\text {th }}$ percentiles for the measurements performed with these sensors are identical and equal $1.3 \% \mathrm{CH}_{4}$. The highest value of the maximum methane concentration before the crossing of the tailgate with the incline II (CSM-5) is $1.6 \% \mathrm{CH}_{4}$ (one case -96 day of observation in Fig. 3). The CSM-1 sensor, in the longwall near its outlet, recorded the highest values of methane concentration equal to $2 \%$ (in 29, 120 and 134 days of observation - Fig. 7). On the $134^{\text {th }}$ day of observation, the concentration of $2 \%$ was also recorded at the CSM-3 sensor located at the tailgate wall in opposite to the longwall outlet, but at CSM-4 sensor in the tailgate, up to $10 \mathrm{~m}$ from the longwall outlet, it reached only $1.0 \% \mathrm{CH}_{4}$.

In at least $75 \%$ days of observation, registered maximum daily methane concentration was in the ranges of:

- at the CSM-1 sensor - $(0.3 \%, 1.6 \%)$,

- at the CSM-4 sensor - $(0.2 \%, 1.5 \%)$,

- at the CSM- 5 sensor - $(0.2 \%, 1.5 \%)$.

The difference between the mean value of the maximum methane concentration and the mean value of the average methane concentration also informs about the variability concentration at the sensor locations:

$-0.33 \% \mathrm{CH}_{4}$ for the CSM- 1 sensor,

$-0.34 \% \mathrm{CH}_{4}$ for the $\mathrm{CSM}-2$ sensor,

$-0.35 \% \mathrm{CH}_{4}$ for the CSM-3 sensor,

$-0.33 \% \mathrm{CH}_{4}$ for the $\mathrm{CSM}-4$ sensor,

- $0.19 \% \mathrm{CH}_{4}$ for the CSM- 5 sensor.

The lowest value occurred for the measurements received from the CSM-5 sensor, which indicates that the smallest variability of registered concentrations occurred at this location. It is related to two factors: the mixture at this location is characterized by high homogeneity and the diffusion phenomenon affects the maximum registered methane concentrations in the tailgate. It could be observed in Figures 3 to 7 as the lowest value ranges between the maximum and average methane concentrations.

In Figures 8 to 15, there are presented a comparison of average and maximum methane concentrations registered by the CSM- 5 sensor (in the tailgate at the distance of $10-15 \mathrm{~m}$ from the incline II crossing) with values registered at the locations of other sensors. The CSM- 5 sensor location is named as the longwall area outlet. 


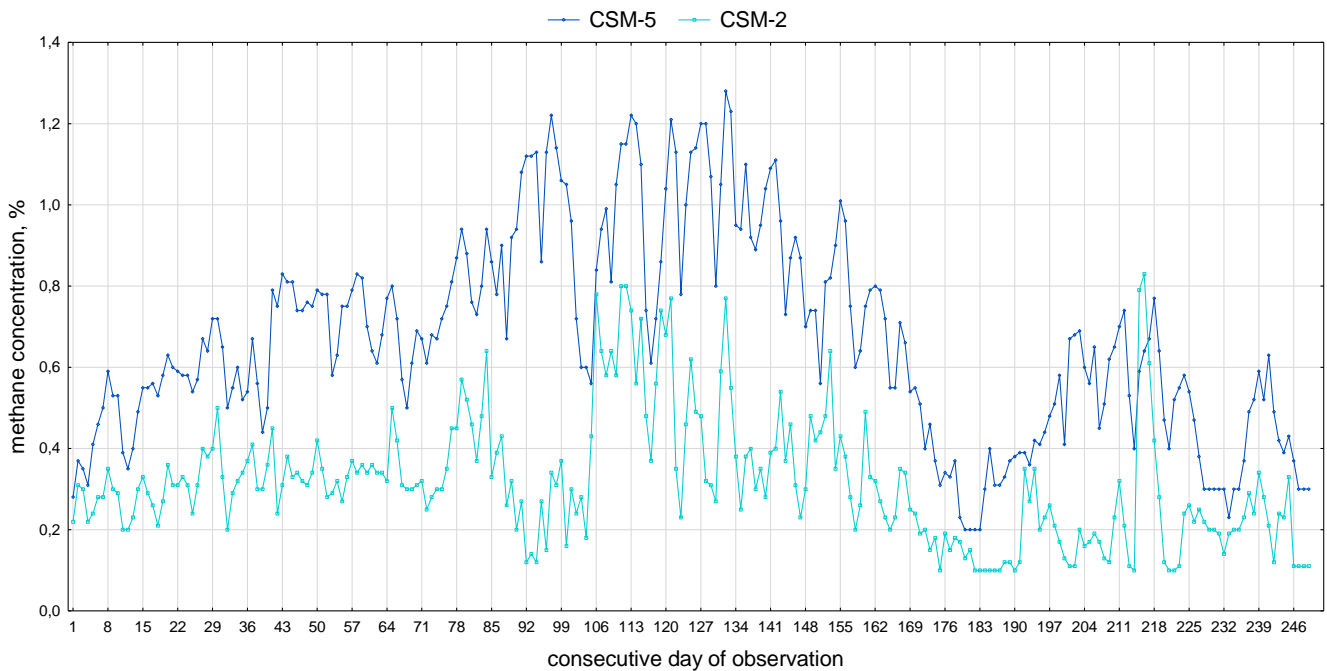

Fig. 8 Average methane concentrations registered up to $2 \mathrm{~m}$ from the tailgate caving line (CSM-2 sensor) and at the longwall area outlet (CSM-5 sensor)

The analysis of the measurements showed that average methane concentrations at the CSM-2 sensor exceeded those at CSM- 5 only in 2 days (the whole set included 249 days). Moreover, the fluctuations of average methane concentration at the tailgate caving line were higher in the particular periods. The correlation coefficient between the discussed values is $r=0.61$. Thus it is quite low (moderate dependence (Zeliaś A., 2000).

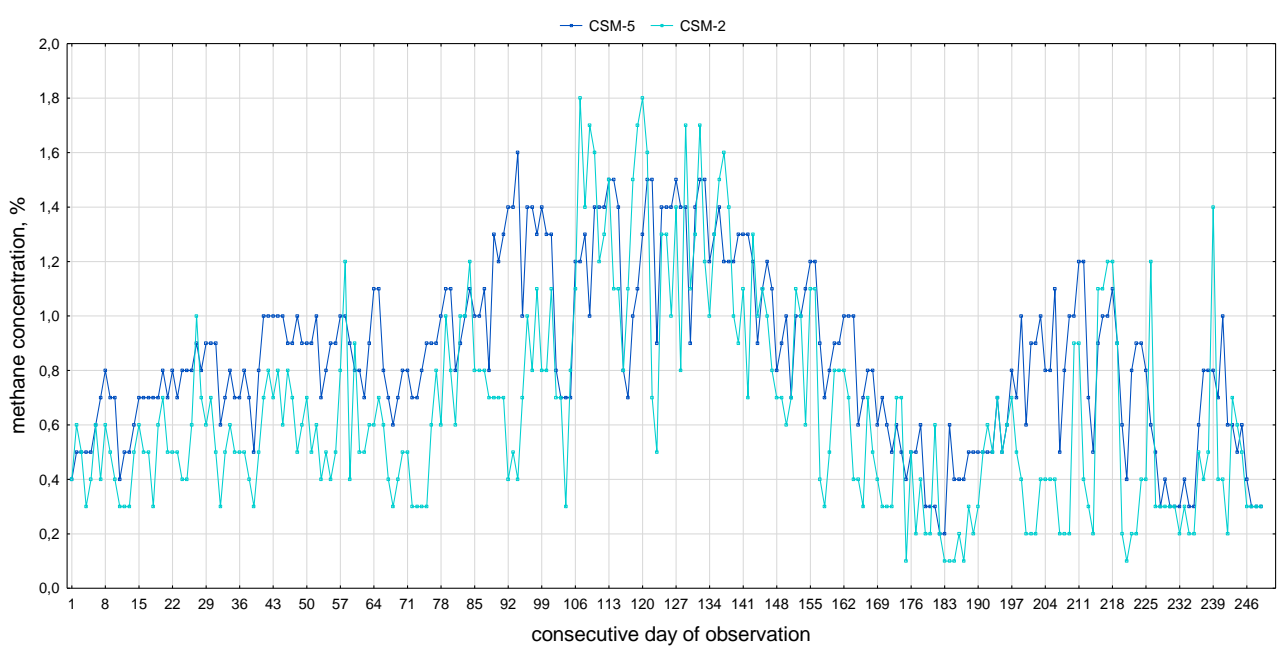

Fig. 9 Maximum methane concentrations registered up to $2 \mathrm{~m}$ from the tailgate caving line (CSM-2 sensor) and at the longwall area outlet (CSM-5 sensor)

The maximum methane concentration measured near the tailgate caving line exceeded this registered at the longwall area outlet in 37 days (almost 15\% of whole observation set). It is significantly more than in average methane concentration comparison. The correlation coefficient of the maximum methane concentration at the CSM-2 and the CSM-5 sensor location is $r=0.71$. It is higher than for average values and indicates significant dependence (Zeliaś A., 2000). 


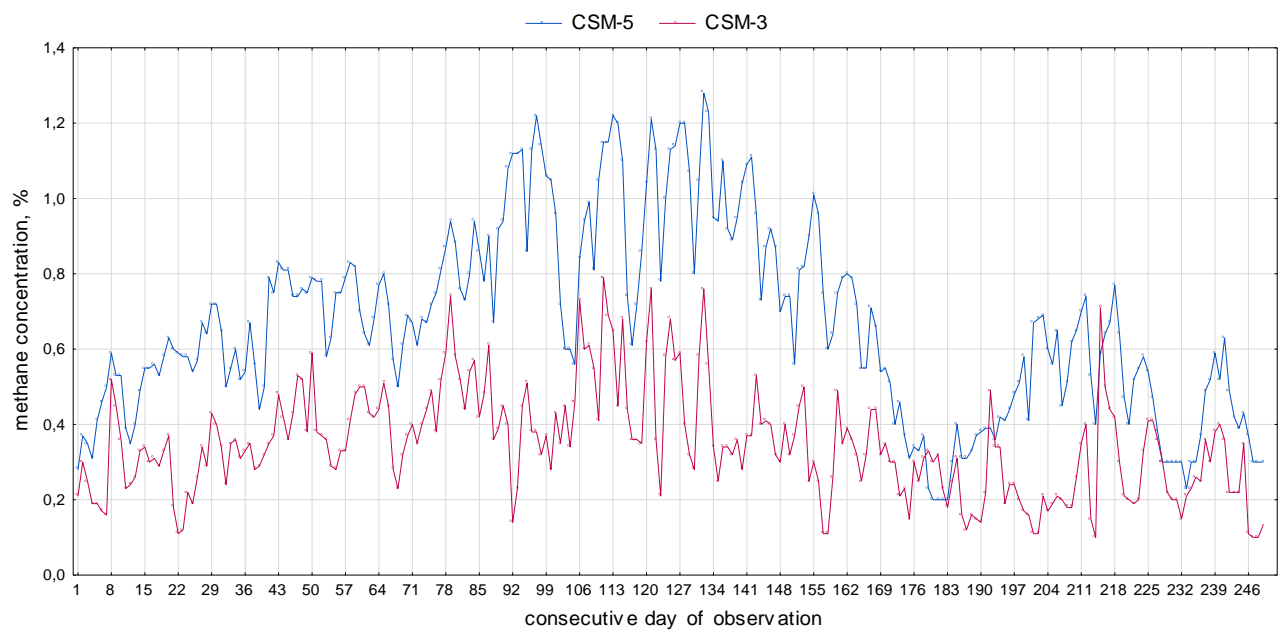

Fig. 10 Average methane concentrations registered in the tailgate wall in opposite to the longwall outlet (CSM-3 sensor) and at the longwall area outlet (CSM-5 sensor)

Comparison of the data presented in Figure 10 shows that the average methane concentration recorded with the CSM-3 sensor exceeded this registered at the CSM-5 in the 6 of 249 days. The correlation coefficient between the discussed average methane concentrations is quite low $-r=0.61$ (moderate dependence (Zeliaś A., 2000)) the same as in the analyzed CSM-2 - CSM-5 correlation. It should also be noted that fluctuations of the concentrations are not always consistent, i.e. the increase in average methane concentration at CSM-3 is not always related to average methane concentration at the longwall area outlet.

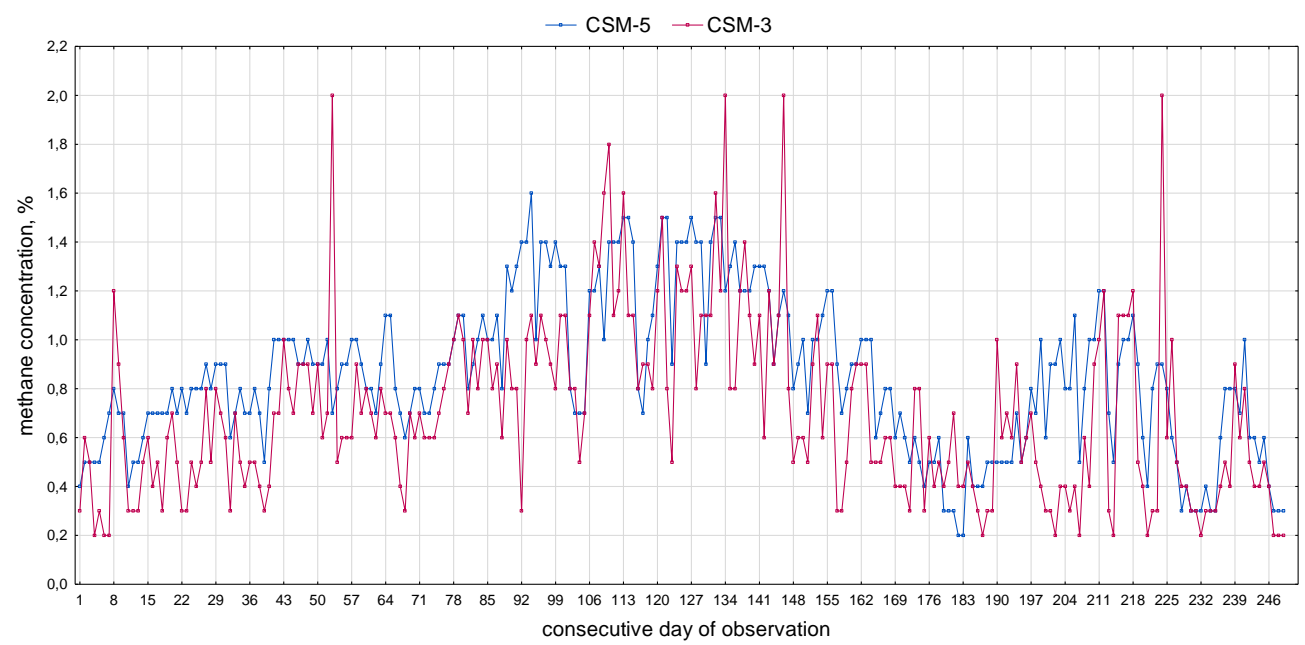

Fig. 11 Maximum methane concentrations registered in the tailgate wall in opposite to the longwall outlet (CSM-3 sensor) and at the longwall area outlet (CSM-5 sensor)

As in the previous case the number of days at which the maximum concentration of methane at CSM-3 exceeded registered at the longwall area outlet was higher than for the average methane concentration. Calculations have shown that it concerns 38 days (ca. 15\% of the whole set). Four times the registered concentration reached $2 \% \mathrm{CH}_{4}$, significantly exceeding maximum measured values on the adjacent days. The correlation coefficient between average values of methane concentration at the CSM-2 sensor location and maximum values 
of methane concentration at the CSM-5 sensor is $r=0.67$, while between maximum values in the mentioned areas is $r=0.68$. Thus, the correlation coefficients values are similar and the considered dependence can be described as moderate (Zeliaś A., 2000).

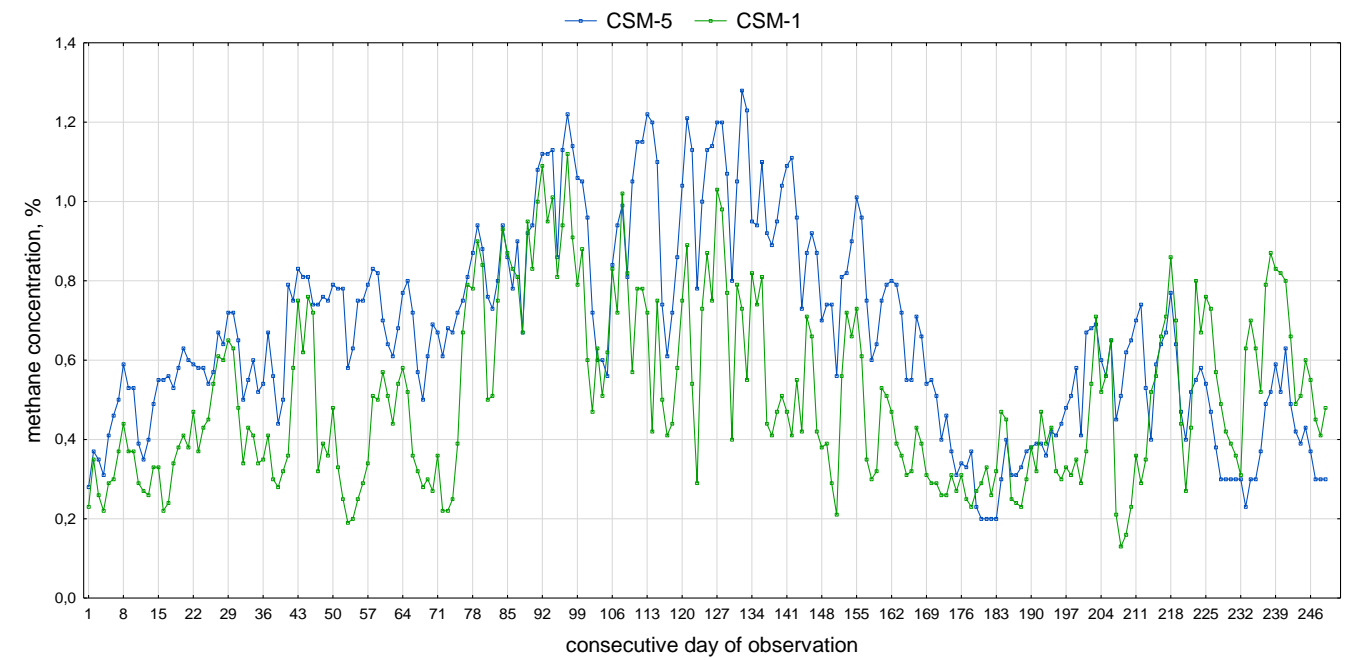

Fig. 12 Average methane concentrations registered in the longwall, in direct vicinity to conveyor drive station (CSM-1 sensor) and at the longwall area outlet (CSM- 5 sensor)

The variability of the average concentration of methane in the longwall outlet was significant. Moreover, the fluctuations of the average concentration often at the CSM-1 sensor were not consistent with this registered at the longwall ventilation area outlet. In the current period of exploitation, the average methane concentration at the longwall ventilation area outlet was higher than at the longwall outlet. However, in 50 cases, the relationship was the opposite. The highest number of such cases were recorded in the final stage of exploitation. The correlation coefficient between the discussed concentrations was quite low as it was $r=0.62$ (moderate dependence (Zeliaś A., 2000).

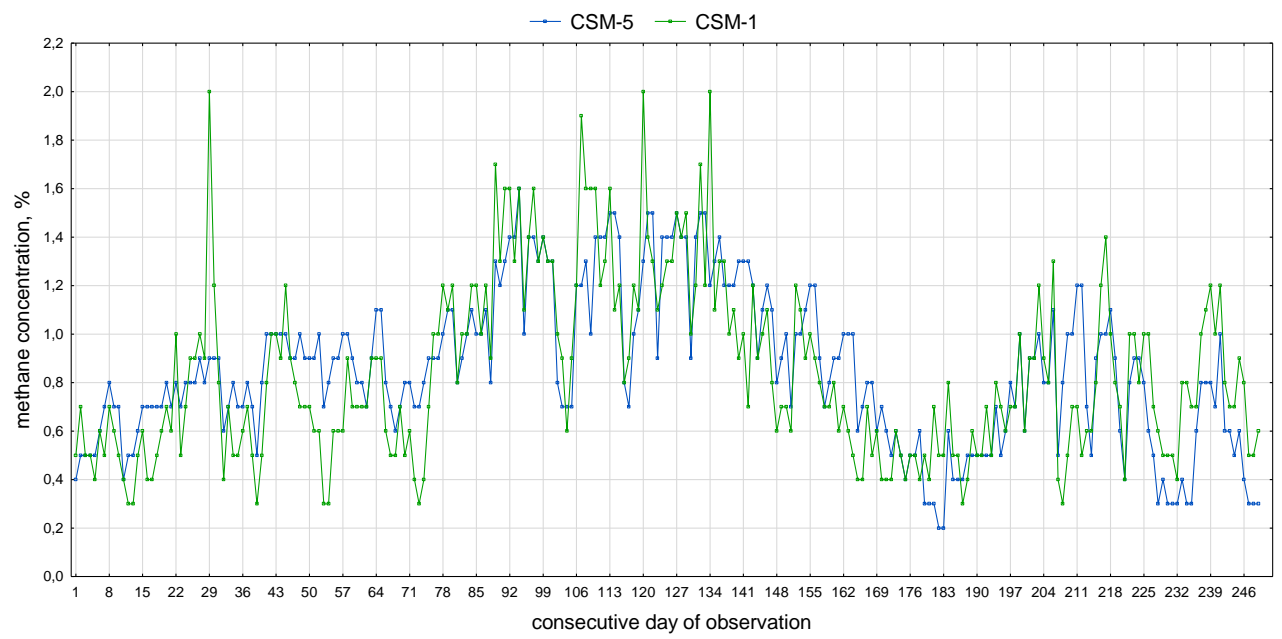

Fig. 13 Maximum methane concentrations registered in the longwall, in direct vicinity to conveyor drive station (CSM-1 sensor) and at the longwall area outlet (CSM-5 sensor) 
The higher values of maximum methane concentration were registered more often in the longwall, near its outlet than at the longwall ventilation area outlet. This exceeding concern 90 days of observation ( $36 \%$ of the whole set). Three times registered maximum methane concentration exceeded $2 \% \mathrm{CH}_{4}$. The correlation coefficient of average methane concentration at the longwall outlet and the maximum methane concentration at the CSM-1 sensor is $r=0.73$. For maximum registered concentrations at the location of sensors CSM- 5 and CSM-1 are $r=0.76$. Thus, the correlation coefficients values are similar and considered dependence is significant (Zeliaś A., 2000).

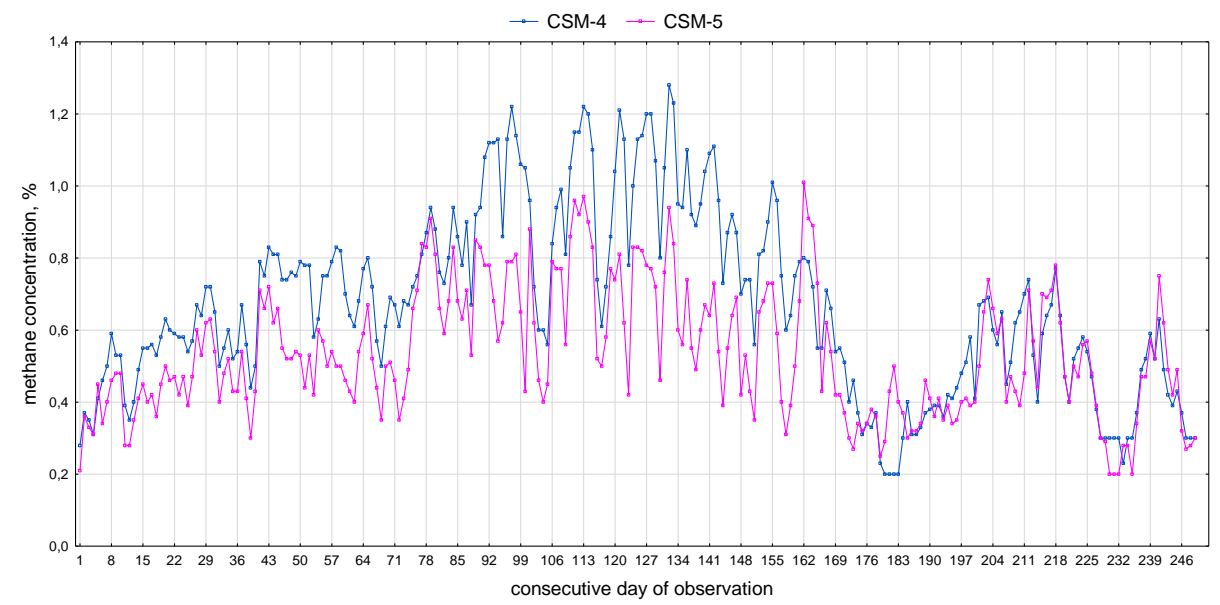

Fig. 14 Average methane concentrations registered in the tailgate, up to $10 \mathrm{~m}$ from the longwall face line (CSM-4 sensor) and at the longwall area outlet (CSM-5 sensor)

The variability of the average methane concentration at the CSM-4 location is characterized by much higher compliance with the variability of this parameter at the outlet from the longwall ventilation area than in previously considered cases.

The correlation coefficient for the considered values is $r=0.82$ (significant dependence (Zeliaś A., 2000) Average methane concentrations at the CSM-4 sensor location are mostly lower than at the CSM-5. 38 exceedances were registered and they often occurred after the $162^{\text {nd }}$ day of observation.

A high correlation value of the maximum methane concentrations at CSM-4 and CSM-5 sensor locations was identified (Fig. 15). However, it should be noted that in 84 considered days (out of 249), the maximum concentrations at CSM-4 excided this registered at the longwall ventilation area outlet. Moreover, in 4 cases, the concentration of $2 \% \mathrm{CH}_{4}$ was exceeded at CSM-4, which was not recorded by the CSM-5 sensor. The correlation coefficient for the average methane concentration at the ventilation area outlet and the maximum concentration up to $10 \mathrm{~m}$ from the longwall face line is $r=0.73$ (significant relationship). For the maximum concentrations at the discussed locations, it assumes $r=0.77$ (significant relationship).

The autocorrelation coefficient has been calculated to check the relationship between the current and preceding day's concentrations. Such information may be helpful for the methane prediction on the next day. 


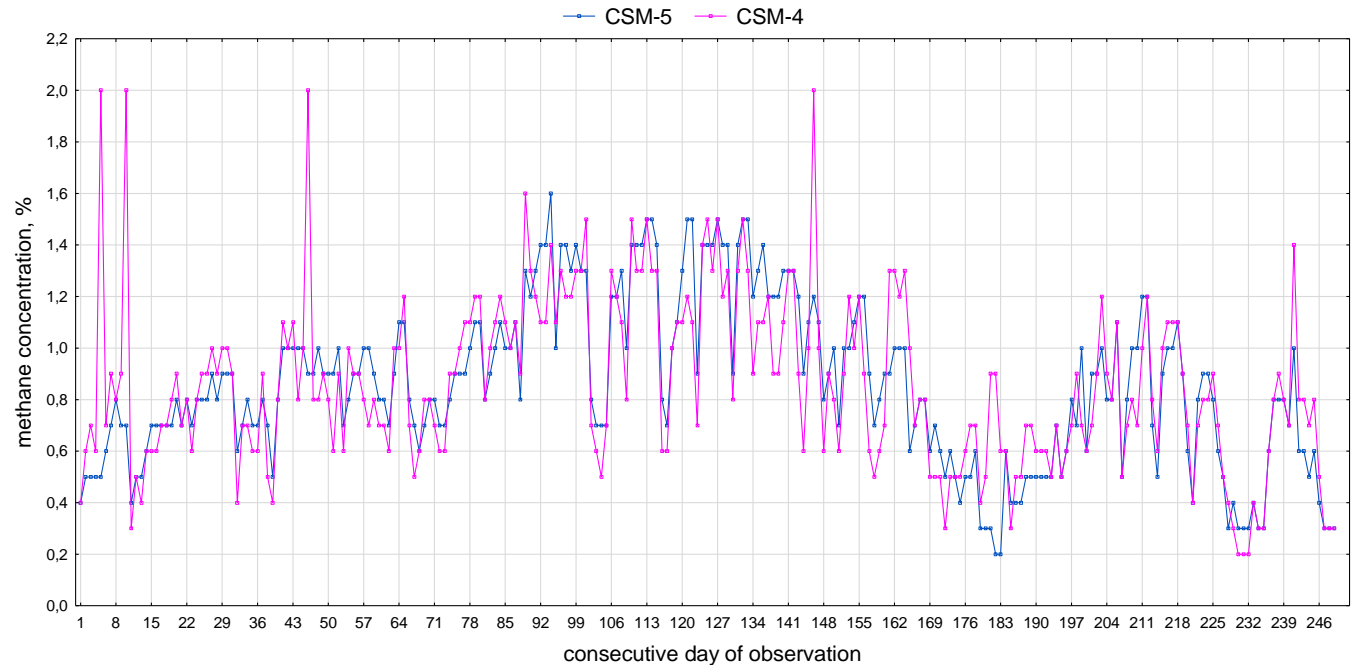

Fig. 15 Maximum methane concentrations registered in the tailgate, up to $10 \mathrm{~m}$ from the longwall face line (CSM-4 sensor) and at the longwall area outlet (CSM-5 sensor)

The coefficient values for the average values of the methane concentrations were: $r_{a}=0.91$ at the longwall ventilation area outlet (CSM-5), $r_{a}=0.76$ in the tailgate, up to $10 \mathrm{~m}$ from the longwall outlet $(\mathrm{CSM}-4), \mathrm{ra}_{\mathrm{a}}=0.66$ at the tailgate wall in opposite to the longwall outlet (CSM-3), $\mathrm{ra}_{\mathrm{a}}=0.75$ up to $2 \mathrm{~m}$ from the tailgate caving line (CSM-2) and $r_{a}=0.79$ at the longwall outlet (CSM-1). Comparison of autocorrelation and correlation coefficients for average methane concentration at the outlet from the ventilation area and in the remaining measurement points shows that only in case of CSM-4 sensor the autocorrelation assumes lower values than correlation coefficient $\left(r_{a}=0.76\right.$ and $r=0.81$ respectively).

Analogously for maximum concentrations the autocorrelation coefficients are: $r_{a}=0.83$ at the CSM-5, $r_{a}=0.53$ at the CSM-4, $r_{a}=0.53$ at the CSM- $3, r_{a}=0.72$ at the CSM-2 and $r_{a}=0.73$ at the CSM-1.

\section{CONCLUSIONS}

The following conclusions can be drawn from the carried out analyses:

1. The paper describes analyses the records acquired from five methane concentration sensors installed in the longwall return air: the CSM-1 located in the longwall, in direct vicinity to conveyor drive station, the CSM-2 located up to $2 \mathrm{~m}$ from the tailgate caving line, the CSM-3 at the tailgate wall in opposite to the longwall outlet, the CSM-4 in the tailgate, up to $10 \mathrm{~m}$ from the longwall outlet and the CSM-5 at the tailgate at a distance of $10-15 \mathrm{~m}$ from the incline II. 2. The average values of methane concentration, calculated for the whole observation period (249 days) based on the registered at sensors CSM-1 to CSM-4 differ significantly from each other, ranging from $0.32 \% \mathrm{CH}_{4}$ to $0.53 \%$ $\mathrm{CH}_{4}$. Also, the mean values of maximum methane concentrations vary and range from $0.66 \% \mathrm{CH}_{4}$ to $0.86 \% \mathrm{CH}_{4}$.

3. The minimum values of average methane concentration in the longwall The autocorrelation coefficient has been calculated to check the relationship between the current and preceding day's concentrations. Such information may 
be helpful for the methane prediction on the next day. The autocorrelation coefficient has been calculated to check the relationship between the current and preceding day's concentrations. Such information may be helpful for the methane prediction on the next day - tailgate crossing area were up to $0.20 \%$ $\mathrm{CH}_{4}$, and the maximum ranged from $0.79 \% \mathrm{CH}_{4}$ to $1.12 \% \mathrm{CH}_{4}$.

4. The conducted analyses showed that the air-methane mixture in the longwall - tailgate crossing area was heterogeneous.

5. The values between the mean and maximum daily average methane concentration range from $0.33 \% \mathrm{CH}_{4}$ (from 10 to $15 \mathrm{~m}$ ahead of the crossing with incline II and $10 \mathrm{~m}$ from longwall outlet) to $0.35 \% \mathrm{CH}_{4}$ (on the tailgate wall opposite the longwall outlet).

6. At the tailgate outlet, the statistical parameters of the average methane concentration in the return air assume the highest values (except for the coefficient of variation). The mean value of average daily methane concentration in the analyzed period was $0.67 \% \mathrm{CH}_{4}$, the minimum registered value was $0.20 \% \mathrm{CH}_{4}$ and the maximum was $1.28 \% \mathrm{CH}_{4}$.

7. According to standard deviation, the highest variability of average methane concentration was found at the outlet from the longwall ventilation area (mean standard deviation equal to $0.25 \% \mathrm{CH}_{4}$ ) and the lowest one - the concentration measured at the sensor located in opposite to the longwall outlet (mean standard deviation equal to $0.14 \% \mathrm{CH}_{4}$ ).

8 . However, relative variability, measured by the coefficient of variation, indicate that the highest variability was observed in the tailgate caving zone (49.7\%), and the lowest at $10 \mathrm{~m}$ from the longwall outlet (33.2\%).

9. The highest mean value of maximum methane concentrations $\left(0.86 \mathrm{CH}_{4}\right)$ occurred at two measurement points - at $10 \mathrm{~m}$ from the longwall outlet and at the tailgate outlet. The lowest mean value of maximum concentration $(0.66 \%$ $\mathrm{CH}_{4}$ ) was recorded at the sensor located near the tailgate caving zone.

10. The lowest values of maximum methane concentration ranged from $0.1 \%$ $\mathrm{CH}_{4}$ to $0.2 \% \mathrm{CH}_{4}$ and the highest recorded values from $1.8 \% \mathrm{CH}_{4}$ to $2 \% \mathrm{CH}_{4}$. 11. The values of $2 \% \mathrm{CH}_{4}$ were recorded by the CSM-1, CSM-3 and CSM- 4 sensors. In total, the sensors registered 11 such events. However, only 2 exceedances were recorded by 2 sensors simultaneously - on the $134^{\text {th }}$ day of operation (CSM-1 and CSM-3 sensors) and the $146^{\text {th }}$ day of operation (CSM-3 and CSM-4 sensors). It confirms the heterogeneity of the air mixture in the area of the longwall outlet.

12. At the tailgate mixing zone, the maximum registered value was $1.8 \% \mathrm{CH}_{4}$ and at the tailgate outlet, near the incline $\mathrm{II}-1.6 \% \mathrm{CH}_{4}$.

13. The highest standard deviation value of the maximum concentration was calculated for data recorded near the tailgate caving line $\left(0.40 \% \mathrm{CH}_{4}\right)$ and the lowest at the tailgate outlet $\left(0.32 \% \mathrm{CH}_{4}\right)$.

14. The highest coefficient of variation value has maximum methane concentration recorded at a distance of up to $2 \mathrm{~m}$ from the tailgate caving line, and the lowest data obtained at the tailgate outlet. 
15. The analysis of average and maximum methane concentration graphs showed that the lowest variability was found for the CSM-5 data.

16. The correlation coefficient of the average methane concentration at the CSM-5 and the CSM- 4 sensors is $r=0,82$, which means a significant correlation. It is the strongest correlation in the whole analyzed dataset.

17. The correlation coefficient of the average methane concentration at the CSM-5 and the maximum methane concentration at the CSM-4 is $r=0.73$, while the correlation coefficient between the maximum methane concentration values at the mentioned locations is $r=0.77$. Both coefficients classify the relationship as significant. These are also the highest correlation values in the whole dataset. 18. Conducted analyses described in this paper will allow further preparation and assessment of the methane concentration forecasting model for longwall outlets.

Conducted analyses will be prepared for the larger dataset, containing various longwalls. The study of methane concentration values distribution at the longwall and tailgate crossing is essential for methane forecasting. Currently used models for the longwall methane forecasting (including methane bearing capacity models) gives no information about possible methane concentration at the locations of the sensor.

The work safety is mainly affected by the temporary occurrence of a given concentration of methane, especially in the area of the longwall and tailgate crossing. The ability to predict the average and maximum methane concentrations will contribute to the increase in safety. Fluctuations in daily average methane concentration are related to the days of the week, daily exploitation volume, minor changes in the methane content in seams and surrounding strata and the formation of the fractured zone. Currently, short-term forecasts of methane concentration allow prediction of the average and maximum concentrations at the tailgate outlet (longwall ventilation area outlet). However, the critical location is the longwall outlet, i.e. the place where the initials of the explosion are most likely to occur. Further in-depth research will allow to prepare a new method for methane prediction in this crucial location of the longwall and possibly help to adjust type, quantity and placement of methane prevention measures.

\section{REFERENCES}

Badura H. (2007a). Analiza wpływu niektórych czynników na metanowość rejonu ściany D-2 w pokładzie 409/4 w KWK „R”. Przegląd Górniczy vol 4, pp. 37-43.

Badura H. (2007b). Analiza stężeń metanu na wylocie z rejonu ściany P-4 w KWK „R”. Górnictwo i Geologia. Kwartalnik. vol 2, pp. 5-16.

Badura H. (2009). Badanie średnich i maksymalnych dobowych stężeń metanu w rejonie ściany D-33 w KWK „Borynia”. Górnictwo i Geologia. Kwartalnik, vol. 3, pp. $19-30$.

Badura H. (2013). Short-term prediction methods for methane concentrations at the outlets from caving longwall areas at coal mines. Monograph. Silesian University of Technology Press, Gliwice.

Berger J., Markiewicz J., Badylak A. (2011). Odmetanowanie kluczem do poprawy bezpieczeństwa i efektywności eksploatacji ścianowej w kopalniach węgla 
kamiennego. In: Metan i jego wykorzystanie, Zakład Odmetanowania Kopalń „ZOK”, Kraków, pp. 75-83

Branny M. (2006). Computer simulation of flow of air and methane mixture in the longwall-return crossing zone. Arch. Mining Science Vol. 51, pp.133-145.

Dittmann P. (2000). Metody prognozowania sprzedaży w przedsiębiorstwie. Wrocław, Wydawnictwo Akademii Ekonomicznej.

Jakubów A. (2014). Doświadczenia w odmetanowaniu kopalń Jastrzębskiej Spółki Węglowej S.A. Pozyskiwanie i utylizacja metanu z pokładów węgla, pp. 61-80.

Karacan C.Ö, Ruiz F.A., Cotè M., Phipps S. (2011). Coal mine methane: A review of capture and utilization practices with benefits to mining safety and to greenhouse gas reduction. International Journal of Coal Geology 86(2-3), pp. 121-156. https://doi.org/10.1016/j.coal.2011.02.009

Karacan C.Ö., Diamond W.P. (2006). Forecasting gas emission for coal mine safety applications. In: Kissel F. (eD.): Handbook for Methane Control in Mining. Information Circular, vol. 9486, National Institute for Occupational Safety and Health. Pittsburgh, PA., pp. 113-126

Karacan C.Ö. (2008). Modeling and prediction of ventilation methane emission of U.S longwall mines using supervised artificial neural networks. International Journal of Coal Geology 73(3-4), pp. 371-387. https://doi.org/10.1016/j.coal.2007.09.003

Karacan C.Ö. (2009). Forecasting gob gas venthole production using intelligent computing methods for optimum methane control in longwall coal mines. International Journal of Coal Geology 79(4), pp. 131-144. https://doi.org/10.1016/j.coal.2009.07.005

Krause E., Łukowicz K. (2000). Dynamiczna prognoza metanowości bezwzględnej ścian. Technical Guide. GIG, KD Barbara Publishing House. Katowice - Mikołów.

Krause E. (2015). Short-Term Predictions of Methane Emissions During Longwall Mining. Arch. Mining Science, vol. 2, pp. 581-594 https://doi.org/10.1515/amsc2015-0038

Krause E., Wierzbiński K. (2009). Wpływ przekrojów wyrobisk oraz uwarunkowań wentylacyjno-metanowych w środowisku ścian na kształtowanie się zagrożenia metanowego. Przegląd Górniczy, vol. 65, pp. 52-60.

Lolon S.A., Brune J.F., Bogin G.E., Grubb J.W., Saki S.A., Juganda A. (2017). Computational fluid dynamics simulation on the longwall gob breathing. International Journal of Mining Science and Technology 27(2), pp. 185-189.

Łunarzewski L.W. (1998). Gas emission prediction and recovery in underground coal mines. International Journal of Coal Geology vol. 35, 1998, pp. 117-145.

Mishra D., Panigrahi D., Kumar P. (2018). Computational investigation on effects of geo-mining parameters on layering and dispersion of methane in underground coal mines- A case study of Moonidih Colliery. Journal of Natural Gas Science and Engineering 53, pp. 110-124. https://doi.org/10.1016/j.jngse.2018.02.030

Noack K. (1998). Control of gas emissions in underground coal mines. International Journal of Coal Geology 35 (1-4), pp. 57-82. https://doi.org/10.1016/S01665162(97)00008-6

Regulation Rozporządzenie Ministra Energii z dnia 23 listopada 2016 r. w sprawie szczegółowych wymagań dotyczących prowadzenia ruchu podziemnych zakładach górniczych. Dz. U. z dnia 9 czerwca 2017 r. poz.1118.

Szlązak N., Obracaj D., Swolkień J. (2014). Methane Drainage from Roof Strata Using and Overlying Drainage Gallery. International Journal of Coal Geology, vol. 136, pp. 99-115. https://doi.org/10.1016/j.coal.2014.10.009

Uszko M., Kloc L., Szarafiński M., Potoczek H. (2014). Pozyskiwanie i zagospodarowanie metanu z odmetanowania kopalń Kompanii Węglowej S.A." In „Pozyskiwanie i utylizacja metanu z pokładów węgla, pp. 185-196.

Wierzbiński K. (2016). Wykorzystanie metod CFD w prognozowaniu przestrzennym rozkładu koncentracji metanu w chodniku wentylacyjnym - opracowanie i walidacja modeli numerycznych 3D. Przegląd Górniczy 72(2), pp. 44-55. 
Zawadzki J., Fabijańczyk P., Badura H. (2013). A risk assessment method to quantitatively investigate the methane explosion in underground coal mine. International Journal of Coal Geology 118, pp. 33-44. https://doi.org/10.1016/j.coal.2013.08.005

Zeliaś A. (2000). Metody statystyczne. Warszawa, Polskie Wydawnictwo Ekonomiczne. Zongyi Q., Liang Y., Hua G., Qingdong Q. (2015). Investigation of longwall goaf gas flows and borehole drainage performance by CFD simulation. International Journal of Coal Geology 150-151, pp. 51-63. https://doi.org/10.1016/j.coal.2015.08.007

\begin{abstract}
.
The methane hazard concerns a growing number of longwalls in the Polish coal mining industry each year. Mitigating this hazard, both of work safety and economic reasons requires the application of preventive measures adequate to its level. Commonly threat level is estimated based on registered methane concentrations, which fluctuate and highly depends on the place of measurement. The article presents studies on the average and maximum methane concentrations at the longwall outlet, including analyses of the interdependence of methane concentration in methanometry sensors installation locations.
\end{abstract}

Keywords: longwall ventilation, coal mine methane, correlation, autocorrelation 